\title{
EDITORIAL
}

\section{Recent Alzheimer's disease research highlights}

\author{
Douglas Galasko*1, Todd Golde*2 and Gordon Wilcock*3
}

As co-editors of Alzheimer's Research and Therapy we would like to highlight several of the major translational research advances that have occurred over the past year, during which a tremendous amount of superb science relevant to the study of Alzheimer's disease (AD) has been published. Our selection is, of course, influenced by our own biases, and selecting particular advances to highlight was challenging. Nevertheless, many major scientific questions relevant to developing better therapies and diagnostics for $\mathrm{AD}$ remain. The advances we have chosen to highlight represent evolving areas of research in $\mathrm{AD}$ that raise as many questions as they answer, but offer some promise that may help us to reach our shared goal of translating research advances into real advances that benefit patients.

\section{Better cellular models of Alzheimer's disease?}

For many years the lack of truly faithful cellular and animal models of $\mathrm{AD}$ has imposed some limitation on what can be inferred from these experimental models. With the technological advances demonstrating that human fibroblasts can be converted into pluripotent stem (iPS) cells and subsequently into neurons, and the promise of this technology to provide new cellular models of human neurodegenerative disease, it was only a matter of time for this technology to be applied to the study of AD.

Over the past year, the first of what are likely to be a plethora of studies examining culture models of $A D$ based on neuronally differentiated iPS cells derived from familial and sporadic AD patients and Down syndrome were published. The first of these demonstrated that fibroblasts from familial AD patients with presenilin 1 or 2 mutations showed altered processing of amyloid $\beta$

*Correspondence: dgalasko@ucsd.edu; tgolde@ufl.edu; gordon.wilcock@ndm.ox.ac.uk

'Department of Neurosciences, University of California, San Diego and VA Medica Center, San Diego, 9500 Gilman Drive, La Jolla, CA 92093-0624, USA

${ }^{2}$ Center for Translational Research in Neurodegenerative Disease, Department of Neuroscience, College of Medicine, McKnight Brain Institute, University of Florida, 1275 Center Drive, BMS J-483, PO Box 100159, Gainesville, FL 32610-0244, USA ${ }^{3}$ Nuffield Department of Medicine, University of Oxford, Level 4, John Radcliffe Hospital, Headington, Oxford, OX3 9DU, UK protein precursor (APP) and increased production of total amyloid $\beta$ protein $(A \beta)$ with increased relative production of $A \beta 42$ [1]. The second included neuronally differentiated iPS cells from reprogrammed fibroblasts of two APP gene duplication carriers, two patients with sporadic $\mathrm{AD}$ and two controls [2]. In the neuronally differentiated iPS cell lines from familial and one of the two sporadic $\mathrm{AD}$ patients, there was higher secretion of $A \beta 40$. A further finding in these three $A D$ cell lines provided a suggestion of interactions with mechanisms of tau pathology: higher levels of phospho-tau and active glycogen synthase kinase (GSK) $3 \beta$. The third and most recent paper conducted similar studies using neuronally differentiated iPS cells from Trisomy 21 patients [3]. When differentiated, these cells showed increased production of $A \beta 42$, increased phospho-tau and perhaps most interesting, the accumulation of $A \beta 42$ aggregates.

Although the alterations in APP and A $\beta$ observed were largely anticipated, based on previous data from human fibroblasts and other biological samples [4], the alterations in tau and GSK3 $\beta$ activity are somewhat surprising. Even more surprising was the demonstration of extracellular A 342 aggregates in long-term iPS Trisomy 21 neuronal cultures. Indeed, no previous culture system to date has reproducibly produced such plaque-like aggregates. If this is reproducible and confirmed to result in a plaque-like structure, it may be possible to utilize such cells to more precisely understand plaque formation under physiologic culture conditions.

Of course with any new technology there remain a number of concerns, and it is not clear whether issues of scale and reproducibility will enable this technology to totally overcome limitations of studying a degenerative brain disease in a culture dish. Though the consistency of the findings across the three studies is reassuring, they still only report on the phenotypes of a handful of cell lines from those at risk for AD. One future application that will be very intriguing is whether iPS cell technology may offer a way to obtain insights into biological mechanisms of genes implicated as risk modifiers in late onset AD $[5,6]$. Hopefully, such future studies will be conducted with appropriate experimental blinding and sufficient power to ensure that the results obtained are widely reproducible. 
Insights into the mechanistic basis for the regional distribution and spread of AD pathology

Classic postmortem studies have framed the characteristic progression and regional distribution of tau and $A \beta$ pathology in the brain. In $\mathrm{AD}$, tau pathology characteristically spreads from the entorhinal cortex into limbic and association cortices as AD evolves [7]. Several studies that have appeared this year provide mechanistic insights into the distribution and spread of tau pathology $[8,9]$.

The microtubule associated protein tau has traditionally been thought to be a cytoplasmic protein. It has been known for some time that soluble tau can be detected in CSF, but its presence in a body fluid was attributed to leakage from dead or dying cells [10]. More recent data from both cell culture studies and in vitro microdialysis suggest that tau and tau aggregates can be constitutively secreted from cells [11]. Moreover, there is evidence that extracellular tau aggregates can seed intracellular aggregation. Two papers published in the last year suggest that tau secretion and subsequent seeding of aggregation can occur in vivo and account for the progression of tau pathology in vivo $[8,9]$. Both of these papers describe studies using transgenic mice expressing the frontotemporal dementia-associated tau P301L mutant in the entorrhinal cortex, and both demonstrated that tau pathology begins in the entorrhinal cortex in these mice but spreads along anatomically connected networks, possibly through synaptic connections. These data are important conceptually as they provide further evidence that tau pathology in $\mathrm{AD}$ may spread through a prion-like conformation-dependent templating reaction mediated by release of tau aggregates from one cell and subsequent internalization by a neighbouring cell. They also provide an explanation for the potential efficacy of anti-tau immunotherapy [12]. Although it is possible that anti-tau antibodies modulate tau pathology by somehow entering neurons and altering tau aggregation, these data would suggest that some anti-tau antibodies may block spread of tau pathology from one cell to another by targeting the extracellular tau transmitted from one cell to another.

\section{Does epigenetic modification offer new insights for developing treatment strategies?}

The role of epigenetic mechanisms, that is, the ability of non-genetic factors to cause genes to express themselves differently without changing their underlying DNA structure, is becoming apparent in an ever increasing number of biological and medical fields and may offer insights into why therapeutic strategies targeting amyloid pathology have been unsuccessful to date. An elegant study reported recently in Nature provides evidence that $A \beta$ may constrain the expression of some memory- and learning-related genes [13]. After these have been 'switched off' by $A \beta$ they cannot be 'switched on' again just by removing the $A \beta$. This process seems to be mediated via a histone deacetylase, HDAC2, which the authors have shown to be activated in brain tissue from both transgenic mouse models, where it reduced synaptic density and memory function, and human AD sufferers. They went on to show that inhibiting HDAC2 restored synaptic plasticity and improved some aspects of memory, although it did not boost the number of surviving neurons in the mice. The pathway is a complex one that also involves the glucocorticoid receptor, GR1.

The implied possibility of reversing pathology, in contrast to slowing decline, is an exciting one but needs further evaluation. HDAC inhibitors are already used or being explored in a number of conditions, for example, oncology, and some pharmaceutical companies are exploring their potential in AD. However, we also need to understand whether such drugs might affect other important but unrelated aspects of genetic function. Roles of epigenetic mechanisms in aging and $\mathrm{AD}$ are likely to be a strong focus of future translational research.

\section{Towards Alzheimer's disease prevention}

Over the past few years the challenges of disease modification in symptomatic patients have become increasingly apparent. Preclinical studies almost invariably show diminishing efficacy with increasing pathology at initiation of treatment. There have been several failed phase III clinical trials with disease modifying agents, though many of these agents were suboptimal with respect to potency, therapeutic window, or brain penetrance. Moreover, even phase II studies with more optimal disease modifying agents fail to show evidence for significant efficacy.

Thus, a clinical highlight of the past year has been a renewed emphasis on designing and implementing more appropriate clinical trial methodology for evaluating disease-modifying treatment in AD. Editorials and reviews have emphasized that disease-modifying treatment in established $\mathrm{AD}$ at the stage of dementia may be too late - the greatest benefit could come from preventing the chain of events that leads to neurodegeneration and irreversible structural changes in the brain [14-17]. Biomarkers exist that are able to identify AD pathology, particularly amyloid deposition, long before cognitive decline begins, and sensitive cognitive tests and paradigms using functional magnetic resonance imaging are showing alterations even during what has been termed 'preclinical $\mathrm{AD}^{\prime}$ ' [16] and the 'asymptomatic at risk' individual [18] and new diagnostic research criteria have been proposed by two working groups.

Treatment trials are at an advanced level of planning in two groups of people at risk for AD. Programmes to clinically identify and characterize carriers of mutations in the presenilin or APP genes, and also systematic initiatives that aim to assess and evaluate biomarkers 
during these presymptomatic stages are under way. The Alzheimer Prevention Initiative [17] has planned a clinical trial in a large population of presenilin 1 E280A mutation-carriers in Colombia, whose natural history and transition from asymptomatic through early symptoms and cognitive deficits to overt dementia has been precisely mapped in a landmark 15 year follow-up study [19]. The international Dominantly Inherited Alzheimer Network group has enrolled and characterized people with different APP and presenilin mutations [20] and is planning an intervention clinical trial in at risk carriers who test positive for amyloid biomarkers. Another initiative more closely relevant to sporadic AD proposes to identify amyloid carriers among elderly subjects who are not cognitively impaired and study their outcomes, using cognitive and imaging measures, over a period of two years [16].

In summary, this has been an exciting year for all of us working to improve treatment for people with AD. Greater understanding of the underlying pathological mechanisms, gained from research using transgenic animals and new stem cell-based technologies, have revealed possible novel therapeutic strategies targeting the underlying pathologies, that is, both $A \beta$ and tau pathology. These developments are complemented by the move to identify pre-dementia $\mathrm{AD}$ and improve trial design. Together they provide hope for the future.

\section{Abbreviations \\ $A \beta$, amyloid $\beta$ protein; $A D$, Alzheimer 's disease; $A P P$, amyloid $\beta$ protein precursor; GSK, glycogen synthase kinase; HDAC, histone deacetylase; iPS, induced pluripotent stem;}

\section{Competing interests}

DG serves on data and safety monitoring boards for clinical trials for Janssen and Elan Pharmaceuticals and for Balance Pharmaceuticals. He is a consultant for Elan Pharmaceuticals, Phloronol, Inc., and United BioSource. TG has served on advisory boards related to preclinical studies for Janssen, Novarits, BristolMyers Squib and Elan Pharmaceuticals. He has received sponsored research grants from Lundbeck and Myriad Pharmaceuticals in the past. GW has served on advisory boards to a number of pharmaceutical companies, including Jannsen, Shire Pharmaceuticals, Lundbeck, Cambridge Neurodiagnostics and Roche. He is a consultant to TauRx. DG, TG and GW are Editors-in-Chief of Alzheimer's Research \& Therapy and receive an annual honorarium.

\section{Published: 18 May 2012}

\section{References}

References indicated with an * are of special interest.

*1. Qiang L, Fujita R, Yamashita T, Angulo S, Rhinn H, Rhee D, Doege C, Chau L, Aubry L, Vanti WB, Moreno H, Abeliovich A: Directed conversion of Alzheimer's disease patient skin fibroblasts into functional neurons. Cell 2011, 146:359-371.

*2. Israel MA, Yuan SH, Bardy C, Reyna SM, Mu Y, Herrera C, Hefferan MP, Van Gorp S, Nazor KL, Boscolo FS, Carson CT, Laurent LC, Marsala M, Gage FH, Remes AM, Koo EH, Goldstein LS: Probing sporadic and familial Alzheimer's disease using induced pluripotent stem cells. Nature 2012, 482:216-220.

*3. Shi Y, Kirwan P, Smith J, MacLean G, Orkin SH, Livesey FJ: A human stem cell model of early Alzheimer's disease pathology in Down syndrome. Sci Transl Med 2012, 4:124ra129.

4. Scheuner D, Eckman C, Jensen M, Song X, Citron M, Suzuki N, Bird TD, Hardy J, Hutton M, Kukull W, Larson E, Levy-Lahad E, Viitanen M, Peskind E, Poorkaj P, Schellenberg G, Tanzi R, Wasco W, Lannfelt L, Selkoe D, Younkin S: Secreted amyloid beta-protein similar to that in the senile plaques of Alzheimer's disease is increased in vivo by the presenilin 1 and 2 and APP mutations linked to familial Alzheimer's disease [see comments]. Nat Med 1996, 2:864-870.

5. Naj AC, Jun G, Beecham GW, Wang LS, Vardarajan BN, Buros J, Gallins PJ, Buxbaum JD, Jarvik GP, Crane PK, Larson EB, Bird TD, Boeve BF, Graff-Radford NR, De Jager PL, Evans D, Schneider JA, Carrasquillo MM, Ertekin-Taner N, Younkin SG, Cruchaga C, Kauwe JS, Nowotny P, Kramer P, Hardy J, Huentelman MJ, Myers AJ, Barmada MM, Demirci FY, Baldwin CT, et al.: Common variants at MS4A4/MS4A6E, CD2AP, CD33 and EPHA1 are associated with late-onset Alzheimer's disease. Nat Genet 2011, 43:436-441.

6. Hollingworth P, Harold D, Sims R, Gerrish A, Lambert JC, Carrasquillo MM, Abraham R, Hamshere ML, Pahwa JS, Moskvina V, Dowzell K, Jones N, Stretton A, Thomas C, Richards A, Ivanov D, Widdowson C, Chapman J, Lovestone S, Powell J, Proitsi P, Lupton MK, Brayne C, Rubinsztein DC, Gill M, Lawlor B, Lynch A, Brown KS, Passmore PA, Craig D, et al.: Common variants at ABCA7, MS4A6A/MS4A4E, EPHA1, CD33 and CD2AP are associated with Alzheimer's disease. Nat Genet 2011, 43:429-435.

7. Braak H, Braak E: Frequency of stages of Alzheimer-related lesions in different age categories. Neurobio/ Aging 1997, 18:351-357.

*8. Liu L, Drouet V, Wu JW, Witter MP, Small SA, Clelland C, Duff K: Trans-synaptic spread of tau pathology in vivo. PLoS One 2012, 7:e31302.

*9. de Calignon A, Polydoro M, Suárez-Calvet M, William C, Adamowicz DH, Kopeikina KJ, Pitstick R, Sahara N, Ashe KH, Carlson GA, Spires-Jones TL, Hyman BT: Propagation of tau pathology in a model of early Alzheimer's disease. Neuron 2012, 73:685-697.

10. Blennow K: Cerebrospinal fluid protein biomarkers for Alzheimer's disease. NeuroRx 2004, 1:213-225.

11. Yamada K, Cirrito JR, Stewart FR, Jiang H, Finn MB, Holmes BB, Binder LI, Mandelkow EM, Diamond MI, Lee VM, Holtzman DM: In vivo microdialysis reveals age-dependent decrease of brain interstitial fluid tau levels in P301S human tau transgenic mice. J Neurosci 2011, 31:13110-13117.

12. Sigurdsson EM: Immunotherapy targeting pathological tau protein in Alzheimer's disease and related tauopathies. J Alzheimers Dis 2008, 15:157-168.

*13. Gräff J, Rei D, Guan JS, Wang WY, Seo J, Hennig KM, Nieland TJ, Fass DM, Kao PF, Kahn M, Su SC, Samiei A, Joseph N, Haggarty SJ, Delalle I, Tsai LH: An epigenetic blockade of cognitive functions in the neurodegenerating brain. Nature 2012, 483:222-226.

14. Golde TE, Schneider LS, Koo EH: Anti-abeta therapeutics in Alzheimer's disease: the need for a paradigm shift. Neuron 2011, 69:203-213.

15. Sperling RA, Jack CR Jr, Aisen PS: Testing the right target and right drug at the right stage. Sci Transl Med 2011, 3:111 cm133.

16. Sperling RA, Aisen PS, Beckett LA, Bennett DA, Craft S, Fagan AM, Iwatsubo T, Jack CR Jr, Kaye J, Montine TJ, Park DC, Reiman EM, Rowe CC, Siemers E, Stern Y, Yaffe K, Carrillo MC, Thies B, Morrison-Bogorad M, Wagster MV, Phelps CH: Toward defining the preclinical stages of Alzheimer's disease: recommendations from the National Institute on Aging-Alzheimer's Association workgroups on diagnostic guidelines for Alzheimer's disease. Alzheimers Dement 2011, 7:280-292.

*17. Reiman EM, Langbaum JB, Fleisher AS, Caselli RJ, Chen K, Ayutyanont N, Quiroz YT, Kosik KS, Lopera F, Tariot PN: Alzheimer's Prevention Initiative: a plan to accelerate the evaluation of presymptomatic treatments. J Alzheimers Dis 2011, 26 Suppl 3:321-329.

18. Dubois B, Feldman HH, Jacova C, Cummings JL, Dekosky ST, BarbergerGateau P, Delacourte A, Frisoni G, Fox NC, Galasko D, Gauthier S, Hampel H, Jicha GA, Meguro K, O'Brien J, Pasquier F, Robert P, Rossor M, Salloway S, Sarazin M, de Souza LC, Stern Y, Visser PJ, Scheltens P: Revising the definition of Alzheimer's disease: a new lexicon. Lancet Neurol 2010, 9:1118-1127.

*19. Acosta-Baena N, Sepulveda-Falla D, Lopera-Gomez CM, Jaramillo-Elorza MC, Moreno S, Aguirre-Acevedo DC, Saldarriaga A, Lopera F: Pre-dementia clinical stages in presenilin 1 E280A familial early-onset Alzheimer's disease: a retrospective cohort study. Lancet Neurol 2011, 10:213-220

*20. Bateman RJ, Aisen PS, De Strooper B, Fox NC, Lemere CA, Ringman JM, Salloway S, Sperling RA, Windisch M, Xiong C: Autosomal-dominant Alzheimer's disease: a review and proposal for the prevention of Alzheimer's disease. Alzheimers Res Ther 2011, 3:1

doi:10.1186/alzrt117

Cite this article as: Galasko D, et al:: Recent Alzheimer's disease research highlights. Alzheimer's Research \& Therapy 2012, 4:14. 